\title{
PERILAKU KONSUMEN GULA PASIR: KETERKAITANNYA DENGAN PENGETAHUAN LABEL, BAURAN PEMASARAN, DAN KESADARAN MEREK
}

\author{
Lyra Majasoka ${ }^{1 *}$, Ujang Sumarwan², Istiqlaliyah Muflikhati ${ }^{2}$ \\ ${ }^{1}$ School of Business, IPB University, Bogor 16880, West Java, Indonesia \\ ${ }^{2}$ Departemen Ilmu Keluarga dan Konsumen, Fakultas Ekologi Manusia, \\ IPB University, Bogor 16880, Indonesia
}

*)E-mail: lyramajas@gmail.com

\begin{abstract}
Abstrak
Pada awalnya produk gula dipasarkan tanpa merek, namun seiring dengan perkembangan industri gula, merek menjadi value added untuk melakukan penjualan. Pemberian brand oleh perusahaan ritel di Indonesia berdampak pada perubahan perilaku pembelian konsumen. Tujuan dari penelitian ini yaitu mengidentifikasi dan menganalisis pengaruh antara variabel pengetahuan konsumen tentang label, brand awareness, dan bauran pemasaran dengan perilaku pembelian produk gula pasir. Penelitian ini melibatkan 200 ibu rumah tangga sebagai responden penelitian. Teknik sampling yang digunakan dalam penelitian ini adalah purposive sampling. Analisis data yang digunakan dalam penelitian ini yaitu analisis deskriptif dan analisis Structural Equation Modeling (SEMPLS). Hasil penelitian menunjukkan bahwa tingkat pengetahuan konsumen tentang label berada pada kategori rendah $(60 \%)$. Hasil dari analisis SEM-PLS menunjukkan bahwa hanya elemen produk pada variabel bauran pemasaran yang memiliki pengaruh signifikan terhadap brand awareness dan perilaku pembelian. Bauran pemasaran (elemen produk) memiliki pengaruh terhadap perilaku pembelian konsumen gula pasir pada atribut kualitas, kemasan, dan merek.
\end{abstract}

Kata kunci: bauran pemasaran, kesadaran merek, pengetahuan label, perilaku pembelian, SEM

\section{Consumer Behavior of Sugar Products: Its Relation with Label Knowledge, Marketing Mix, and Brand Awareness}

\begin{abstract}
Initially, sugar products were marketed without a brand, but along with the development of the sugar industry, brands became a value-added for sales. Branding by retail companies in Indonesia has an impact on changing consumer buying behavior. The purpose of this study is to identify and analyze the influence of the variable consumer knowledge about labels, brand awareness, and marketing mix with the buying behavior of granulated sugar products. The research involved 200 housewives as research respondents. The sampling technique used in this study was purposive sampling. The data analysis used in this research is descriptive analysis and analysis of Structural Equation Modeling (SEM-PLS). The results showed that the level of consumer knowledge about labels was in a low category (60\%). The results of the SEM-PLS analysis show that only product elements in the marketing mix variable have a significant effect on brand awareness and purchasing behavior. The marketing mix (product element) has an influence on the consumer purchasing behavior of sugar on the attributes of quality, packaging, and brand.
\end{abstract}

Keywords: brand awareness, consumer purchase behavior, label knowledge, marketing mix, SEM

\section{PENDAHULUAN}

Produk gula merupakan salah satu komoditas yang berperan penting dalam konsumsi seharihari pada masyarakat Indonesia. Gula adalah salah satu bahan pangan pokok yang mengalami peningkatan konsumsi dari tahun 2013 hingga 2017 sekitar lima persen (BPS, 2017). Menurut Sugiyanto (2007), tingginya tingkat konsumsi gula disebabkan oleh kalori dalam gula yang dapat menjadi alternatif sumber energi, bahan pengawet yang tidak membahayakan kesehatan pemakainya, dan kecilnya kecenderungan untuk mensubsitusikan gula dengan pemanis lain. Permintaan gula secara nasional akan terus meningkat seiring dengan berkembangnya demografi penduduk, seperti; peningkatan jumlah penduduk, pendapatan masyarakat, dan pertumbuhan industri pengolahan makanan dan minuman. Perilaku pembelian (consumer purchase behavior) yang dilakukan konsumen mencakup 
proses pengambilan keputusan konsumen mengenai jenis produk yang akan dibeli, tempat membeli, dan cara pembayaran (Sumarwan, 2015).

Pada penelitian sebelumnya (Putri, Darus, dan Ayu, 2012) terkait faktor berpengaruh pada konsumsi dan keputusan pembelian konsumen gula pasir yaitu harga beli, pendapatan, dan jumlah keluarga. Konsumsi produk gula perlu disesuaikan dengan olahan produk dan cita rasa sesuai keinginan konsumen. Hal inilah yang menyebabkan di pasaran telah tersedia berbagai macam jenis gula. Namun, pada hasil survei nasional yang dirilis oleh Badan Pusat Statistik (BPS) Tahun 2017 menjelaskan bahwa gula dapat dikelompokkan menjadi dua jenis yaitu gula pasir dan gula merah. Konsumsi per kapita dalam satu minggu selama lima tahun terakhir masih didominasi oleh gula pasir dibandingkan dengan gula merah. Perbedaan jumlah rata-rata konsumsi gula pasir dengan gula merah sekitar delapan persen.

Gula pasir yang ditujukkan untuk konsumsi pribadi, rumah tangga, dan usaha di bidang kuliner dalam skala Usaha Mikro, Kecil, Menengah (UMKM) menggunakan kemasan plastik untuk mempermudah konsumen saat berbelanja. Kemasan produk gula pasir merupakan bagian dari atribut produk yang terdiri dari nama merek atau nama dagang, nama produk, nama produsen, komposisi, logo Standar Nasional Indonesia (SNI), Badan Pengawas Obat dan Makanan Republik Indonesi (BPOM RI), Halal Majelis Ulama Indonesia (MUI), klaim produk, berat bersih, dan tanggal kadaluarsa.

Peraturan tentang labelling diatur dalam Peraturan Menteri Perdagangan Republik Indonesia Nomor 73/M-DAG/PER/9/2015 tentang Kewajiban Pencantuman Label dalam Bahasa Indonesia pada Barang dan Peraturan Kepala Badan Pengawas Obat dan Makanan Republik Indonesia Nomor 13 Tahun 2016 (BPOM, 2016) tentang Pengawasan Klaim pada Label dan Iklan Pangan Olahan Pasal 1 ayat 14. Menurut Durianto (2011) dalam Sunaryo dan Sudiro (2017), label adalah suatu informasi pada produk yang diharapkan dapat membuat konsumen merasa aman untuk mengonsumsi produk tersebut.

Berdasarkan penelitian Goodson (2013), label makanan yang tercantum pada kemasan produk merupakan salah satu faktor yang berpengaruh pada konsumen untuk melakukan keputusan pembelian produk. Atribut lain selain label yang tercantum pada kemasan produk yaitu nama merek atau brand. Pada awalnya gula dipasarkan tanpa merek, namun seiring dengan perkembangan industri gula, merek menjadi salah satu value-added bagi produsen untuk melakukan penjualan gula pasir menggunakan brand. Suatu fenomena pemberian brand oleh seluruh perusahaan ritel di Indonesia, disebut sebagai private brand. Private brand menurut Ma'ruf (2006) merupakan suatu produk kebutuhan sehari-hari yang dijual dan didistribusikan pada masingmasing gerai sesuai peritel tersebut. Persaingan di industri gula terjadi karena produsen gula berasal dari perusahaan peritel dengan private brand dan perusahaan Fast Moving Consumer Goods (FMCG).

Dampak dari persaingan yang dihadapi peruhasaan produsen gula pasir yaitu perusahaan sulit memperoleh laba marjin. Harga gula di Indonesia tidak mengikuti mekanisme pasar dan wajib mengikuti penetapan pemerintah karena gula merupakan salah satu komoditi kebutuhan pokok dan cukup berpengaruh signifikan terhadap inflasi (Tayibnapis et al., 2016). Berdasarkan beberapa hal tersebut, perusahaan gula pasir mengalami kesulitan untuk menyesuaikan harga jual berdasarkan daya beli konsumen dan penyesuaian biaya produksi. Dari sisi konsumen, harga produk gula memiliki perbedaan yang tidak terlalu signifikan namun dijadikan pertimbangan dalam membeli produk tersebut.

Berdasarkan riset yang dilakukan Anggraini, Prasmatiwi, dan Santoso (2013) pada salah satu merek ternama gula pasir di Indonesia, loyalitas konsumen terhadap pembelian suatu merek hanya berdasarkan faktor kebiasaan. Analisis path yang dilakukan pada penelitian terebut menyatakan bahwa elemen produk, harga, tempat, dan promosi tidak memiliki pengaruh signifikan terhadap variabel kepuasaan dan loyalitas konsumen. Brand awareness merupakan faktor lain dalam proses keputusan konsumen saat menentukan pilihan produk yang akan dibeli.

Penelitian Setiawati dan Lumbantobing (2017) melalui analisis jalur menunjukkan bahwa brand awareness berpengaruh signifikan terhadap keputusan pembelian. Selain label dan brand awareness, faktor lain yang memengaruhi perilaku pembelian (consumer purchase behavior) yaitu bauran pemasaran yang terdiri dari produk, harga, tempat, dan promosi (Kotler \& Keller, 2017). Penelitian Pupuani dan Sulistyawati (2012); Siringoringo (2004); dan Wongleedee (2015) menyebutkan bahwa 
bauran pemasaran dengan perilaku pembelian memiliki pengaruh yang signifikan.

Permasalahan lainnya terkait gula pasir terdapat pada tingkat pengetahuan konsumen terkait label yang berada pada kategori rendah yaitu hanya 6,7 persen konsumen yang memerhatikan kelengkapannya atribut produk tersebut berdasarkan hasil kajian badan perlindungan konsumen (BPKN, 2007) di bidang pangan terkait perlindungan konsumen.

Lebih lanjut, hal tersebut memicu penelitian ini untuk melihat bagaimana perilaku pembelian konsumen gula pasir, jika dilihat dari variabel bauran pemasaran, tingkat pengetahuan konsumen terkait label, dan brand awareness konsumen terhadap seluruh merek gula pasir yang dijual di pasaran sehingga perspektif merek gula pasir dari sisi konsumen dapat dilihat secara lebih luas. Kebaruan pada penelitian ini yaitu melakukan analisis dengan objek yang lebih luas (seluruh merek gula pasir).

Oleh karennya, tujuan penelitian ini, yaitu: mengidentifikasi pengetahuan konsumen tentang label, brand awareness, bauran pemasaran, dan perilaku pembelian gula pasir; dan menganalisis pengaruh pengetahuan label, brand awareness, dan bauran pemasaran terhadap perilaku pembelian gula pasir.

\section{METODE}

Penelitian ini dilaksanakan di wilayah Kota Bogor dengan metode pengambilan sampel penelitian adalah teknik convenience. Kriteria sampel pada penelitian ini yaitu berdasarakan pengamatan penulis pada konsumen yang telah melakukan pembelian gula pasir pada saat pengambilan data. Objek dari penelitian ini adalah individu yang melakukan kegiatan pembelian, mengolah, dan mengonsumsi gula. Sampel penelitian ini adalah ibu rumah tangga dengan jumlah 200 responden. Sampel penelitian ini yaitu ibu rumah tangga yang sedang berbelanja di minimarket, supermarket, dan pasar tradisional. Data primer dalam penelitian ini didapat dari hasil wawancara dengan responden dengan menggunakan panduan kuesioner. Data primer tentang karakteristik responden, pengetahuan label, brand awareness, bauran pemasaran, dan perilaku pembelian.

Variabel penelitian ini terdiri atas variabel independen dan variabel dependen. Variabel independen $(\mathrm{X})$ pada penelitian ini meliputi pengetahuan label, brand awareness, dan elemen bauran pemasaran. Pengetahuan label merupakan pengetahuan subjektif konsumen terhadap berbagai informasi yang terdapat pada label produk. Kuesioner terkait pengetahuan label dimodifikasi dari Muslim dan Indriyani (2014). Pada penelitian ini pengetahuan konsumen dispesifikkan menjadi pengetahuan terkait label seperti peraturan (PL1), jenis (PL2), simbol (PL3), dan istilah (PL4).

Kuesioner pengetahuan label terdiri dari sembilan pertanyaan dengan nilai Cronbach's alpha 0,145. Cara pengukuran variabel penelitian pengetahuan konsumen terkait label dan variabel bauran pemasaran menggunakan skala Likert 1 hingga 5 (1=Sangat tidak setuju 2=Tidak setuju 3=Netral 4=Setuju 5=Sangat setuju). Variabel pengetahuan konsumen terkait label, sebaran jawaban responden dikelompokkan kembali menjadi top two boxies, dengan kategori tidak tahu dan tahu.

Brand awareness merupakan sebuah kesanggupan seorang calon pembeli untuk mengenali dan mengingat merek sebagai bagian dari suatu produk dengan merek yang dilibatkan. Pada penelitian ini, variabel brand awareness digambarkan melalui beberapa pertanyaan spesifik terkait brand dari produk gula pasir sehingga berbeda dengan variabel lain (bauran pemasaran atau pengetahuan label). Hal ini karena brand awareness hanya digunakan untuk menggambarkan bagaimana posisi suatu merek produk tertentu (gula pasir) di benak konsumen.

Kuesioner terkait brand awareness diadopsi dari penelitian Suroyo (2012) dengan 3 pertanyaan. Cara pengukuran variabel brand awareness menggunakan asumsi kondisi berdasarkan golongan merek, dengan skor 1 hingga 5. Berikut ini asumsi kondisi yang digunakan pada penelitian ini, skor $1=$ merk yang digunakan tergolong ke dalam kategori brand unaware dari responden, skor 2=merk yang digunakan tergolong ke dalam kategori brand recognition dari responden, skor $3=$ merk yang digunakan tergolong ke dalam kategori brand recall dari responden, skor $4=$ merk yang digunakan tergolong ke dalam kategori top of mind dari responden dan lebih dari 2 merek dievaluasi dalam proses perilaku pembelian, dan skor $5=$ merk yang digunakan tergolong ke dalam kategori top of mind dari responden dan hanya 1 merek dievaluasi dalam proses perilaku pembelian.

Bauran pemasaran (marketing mix) merupakan suatu taktik untuk membangun merek (brand 
building) dan mencapai target penjualan. Kuesioner bauran pemasaran dimodifikasi dari Rasyid (2016). Variabel bauran pemasaran dibagi menjadi empat elemen yaitu produk, tempat, harga, dan promosi. Secara berurutan elemen harga, tempat, produk, dan promosi memiliki nilai Cronbach's alpha 0,$634 ; 0,837$; 0,$837 ; 0,813$.

Pada variabel bauran pemasaran produk terdapat indikator seperti merek produk (BPP1), warna (BPP2), tekstur (BPP3), kebersihan (BPP4), tingkat kekeringan gula (BPP5), dan label (BPP6). Pada variabel harga, indikator yang digunakan yaitu persepsi konsumen tentang harga kategori murah (BPH1) dan kelengkapan atribut produk sesuai harga (BPH2). Pada variabel promosi, terdapat indikator seperti promosi penjualan (BP1) dan media promosi yang digunakan oleh produsen gula pasir (BP2).

Perilaku pembelian (consumer purchase behavior) adalah keputusan konsumen terkait pertimbangan merek yang dibeli, waktu membeli, dan atribut produk yang dipentingkan. Kuesioner perilaku pembelian di modifikasi dari Fitriyani (2016) dengan nilai Cronbach's alpha instrumen adalah 0,736 dan diukur melalui skala Likert 1 hingga 5 dengan sistem poin sangat tidak setuju (STS) hingga sangat sejutu (SS). Perilaku pembelian dalam penelitian ini diukur melalui indikator seperti perilaku pembelian gula pasir berlabel (PP1), perilaku pembelian gula pasir bermerek (PP2), dan perilaku pembelian gula pasir dengan pertimbangan kelengkapan pada atibut poduk (PP3).

Metode pengolahan dan analisis data disajikan secara deskriptif dan dianalisis secara kuantitatif serta kualitatif. Analisis deskriptif digunakan untuk manggambarkan data tanpa bermaksud menggenaralisir atau membuat kesimpulan (hanya menjelaskan kelompok data primer tertentu). Adapun data yang dianalisis secara deskriptif, yaitu karakteristik responden (demografi), pengetahuan label gula pasir, penilaian konsumen terhadap tingkat brand awareness pada produk gula pasir, dan perilaku pembelian (consumer purchase behavior). Analisis PLS-SEM digunakan untuk melihat pengaruh bauran pemasaran, brand awareness, dan pengetahuan label terhadap perilaku pembelian gula pasir. Partial Least Square merupakan salah satu metode alternatif SEM yang memiliki asumsi data penelitian bebas distribusi, sehingga dapat diartikan bahwa data penelitian tidak mengacu pada salah satu distribusi tertentu Yamin dan Kurniawan (2009). Penelitian ini menggunakan model struktural SEM-PLS perilaku pembelian konsumen pada produk gula pasir yang ditampilkan pada Gambar 1.

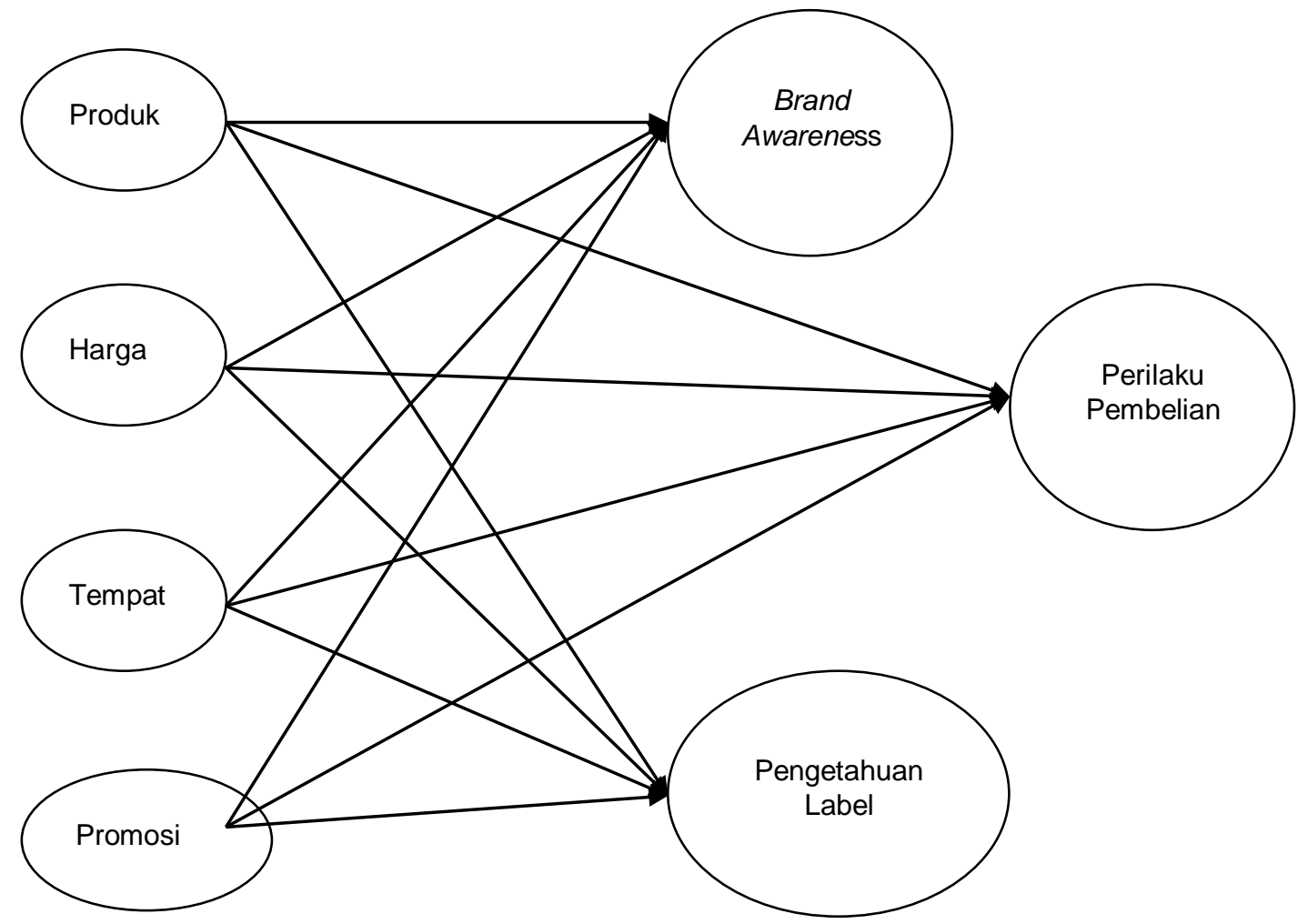

Gambar 1 Model SEM-PLS perilaku pembelian produk gula pasir 


\section{HASIL}

\section{Karakteristik Responden}

Responden penelitian ini terdiri dari wanita yang didominasi dengan dua kategori usia yaitu 26-35 tahun (34\%) dan 36-45 tahun (33\%). Selain itu, lebih dari setengah responden (51\%) memiliki latar belakang pendidikan Sarjana (S1). Jenis pekerjaan responden didominasi oleh pegawai swasta (33\%) dan ibu rumah tangga $(30 \%)$ sebagai jenis pekerjaan tertinggi kedua. Hasil lain menunjukkan bahwa tingkat pengeluaran makanan dan minuman konsumen per bulan sebesar Rp2.000.000,00 hingga Rp4.000.000,00.

\section{Variabel Pengetahuan Label Gula Pasir}

Pengetahuan konsumen terkait label pada kemasan gula pasir berada di kategori rendah. Hal tersebut ditunjukkan dari sembilan pertanyaan terkait pengetahuan label, persentase terbesar responden dengan jawaban benar berada pada pertanyaan terkait logo SNI (Standar Nasional Indonesia), BPOM (Badan Pengawas Obat dan Makanan) RI, atau Halal MUI.

Tabel 1 Pengetahuan konsumen terkait label gula pasir

\begin{tabular}{|c|c|c|}
\hline Indikator & Mengetahui & $\begin{array}{c}\text { Tidak } \\
\text { mengetahui }\end{array}$ \\
\hline $\begin{array}{l}\text { Produk pangan olahan } \\
\text { wajib mencantumkan } \\
\text { label pangan (PL1) }\end{array}$ & 11,5 & 88,5 \\
\hline $\begin{array}{l}\text { Peraturan label pangan } \\
\text { diatur peraturan Menteri } \\
\text { Perdagangan Republik } \\
\text { Indonesia (PL1) }\end{array}$ & 16,5 & 83,5 \\
\hline $\begin{array}{l}\text { Peraturan label pangan } \\
\text { diatur BPOM Republik } \\
\text { Indonesia (PL1) }\end{array}$ & 14,0 & 86,0 \\
\hline $\begin{array}{l}\text { Label tercantum pada } \\
\text { kemasan produk gula } \\
\text { (PL2) }\end{array}$ & 31,5 & 68,5 \\
\hline $\begin{array}{l}\text { Label SNI tercantum } \\
\text { pada kemasan produk } \\
\text { gula (PL3) }\end{array}$ & 78,0 & 22,0 \\
\hline $\begin{array}{l}\text { Logo halal pada } \\
\text { kemasan produk gula } \\
\text { (PL3) }\end{array}$ & 64,5 & 35,5 \\
\hline $\begin{array}{l}\text { Label BPOM RI pada } \\
\text { kemasan produk gula } \\
\text { (PL4) }\end{array}$ & 88,5 & 11,5 \\
\hline $\begin{array}{l}\text { Label komposisi pada } \\
\text { kemasan produk gula } \\
\text { (PL4) }\end{array}$ & 12,0 & 88,0 \\
\hline $\begin{array}{l}\text { Label No. PIRT pada } \\
\text { kemasan produk gula } \\
\text { (PL4) }\end{array}$ & 25,5 & 74,5 \\
\hline
\end{tabular}

Penelitian ini menunjukkan bahwa responden dengan jenis kelamin perempuan tidak terlalu memrioritaskan label sebagai suatu atribut penting dalam perilaku pembelian produk gula pasir. Tingkat pengetahuan konsumen terkait label gula pasir terdapat pada Tabel 1, dengan keterangan sebagai berikut STS=sangat tidak setuju TS=tidak setuju $\mathrm{N}=$ netral $\mathrm{S}=$ setuju $\mathrm{SS}=$ sangat setuju.

\section{Brand Awareness}

Berdasarkan hasil penelitian diketahui bahwa terdapat 17 merek di pasaran yang sudah diketahui konsumen. Merek gula pasir dikategorikan berdasarkan jenis perusahaan produsen, yaitu; perusahaan Fast Moving Consumer Goods (FMCG) dan perusahaan retail dengan produk private label. Dimensi brand awareness yang digunakan dalam penelitian ini dibagi menjadi empat tingkatan yaitu brand unaware, brand recogition, brand recall, dan top of mind.

Berdasarkan hasil penelitian, diketahui bahwa hampir seluruh konsumen menyebutkan salah satu merek yang terlintas pertama kali saat menyebutkan produk gula pasir yang menandakan merek tersebut berada pada tingkatan Top of Mind. Tingkatan dimensi setelah Top of Mind yaitu brand recall yang merujuk pada tahapan konsumen mampu mengingat suatu brand tanpa dibantu. Dimensi lain yang berada di bawah brand recall yaitu brand recognition. Pada tahapan ini konsumen mampu mengenali merek sebagai suatu petunjuk dengan diberikan rangsangan mengenai satu kategori tertentu. Tingkatan brand awareness yang berada pada piramida paling bawah yaitu brand unaware yang menunjukkan bahwa konsumen tidak mengenali merek tersebut. Merek-merek yang berada pada kategori brand unaware merupakan merek baru, sehingga belum dapat mendominasi pasar. Merek-merek pada kategori brand unaware dijadikan pengganti oleh konsumen jika merek yang lebih dikenal konsumen tidak tersedia.

\section{Bauran Pemasaran}

Bauran pemasaran pada penelitian ini dibagi menjadi empat elemen diantaranya bauran pemasaran harga, bauran pemasaran promosi, bauran pemasaran tempat, dan bauran pemasaran produk. Berdasarkan hasil penelitian pada Tabel 2 jawaban responden pada variabel bauran pemasaran menyebar secara merata pada elemen harga, tempat, dan promosi. 
Tabel 2 Bauran pemasaran konsumen terhadap produk gula pasir

\begin{tabular}{|c|c|c|c|c|c|}
\hline \multirow{3}{*}{ Variabel } & \multirow{3}{*}{ Indikator } & \multirow{3}{*}{ Simbol } & \multicolumn{3}{|c|}{ Presentase (\%) } \\
\hline & & & \multirow{2}{*}{$\begin{array}{l}\text { STS+TS } \\
\text { Rendah }\end{array}$} & \multirow{2}{*}{$\frac{\mathrm{N}}{\mathrm{Sedang}}$} & \multirow{2}{*}{$\begin{array}{l}\text { S+SS } \\
\text { Tinggi }\end{array}$} \\
\hline & & & & & \\
\hline \multicolumn{6}{|c|}{ Bauran pemasaran } \\
\hline \multirow[t]{7}{*}{ Produk } & $\begin{array}{l}\text { Gula pasir harus diberi merek atau } \\
\text { brand }\end{array}$ & BPP1 & 4,5 & 18,5 & 77,0 \\
\hline & $\begin{array}{l}\text { Warna gula pasir harus berwarna } \\
\text { putih jernih }\end{array}$ & BPP2 & 27,5 & 35,5 & 37,0 \\
\hline & $\begin{array}{l}\text { Butiran gula pasir bertekstur atau } \\
\text { tidak halus }\end{array}$ & BPP3 & 12,5 & 21,5 & 65,5 \\
\hline & Butiran gula pasir bersih & BPP4 & 10,5 & 20,0 & 69,5 \\
\hline & $\begin{array}{l}\text { Tingkat kekeringan gula pasir } \\
\text { merupakan indikator gula pasir } \\
\text { kualitas baik }\end{array}$ & BPP5 & 4,5 & 13,0 & 82,5 \\
\hline & $\begin{array}{l}\text { Kualitas kemasan gula pasir } \\
\text { dengan label dalam kondisi sesuai } \\
\text { standard }\end{array}$ & BPP6.1 & 4,5 & 12,5 & 83 \\
\hline & Produk gula harus disertai label & BPP6.2 & 3,5 & 14,5 & 82 \\
\hline \multirow[t]{3}{*}{ Harga } & $\begin{array}{l}\text { Harga merk gula pasir yang saya } \\
\text { beli memiliki harga sebanding } \\
\text { dengan gula pasir merek lain }\end{array}$ & $\mathrm{BPH} 1$ & 11,5 & 22,0 & 66,5 \\
\hline & $\begin{array}{l}\text { Meski harga gula pasir dengan } \\
\text { label lebih mahal, namun saya } \\
\text { tetap membeli }\end{array}$ & BPH2.1 & 14,5 & 25,0 & 60,5 \\
\hline & $\begin{array}{l}\text { Harga gula pasir dengan kemasan } \\
\text { dan label memiliki harga jual } \\
\text { sesuai }\end{array}$ & BPH2.1 & 7,5 & 15,5 & 77,0 \\
\hline \multirow[t]{5}{*}{ Tempat } & $\begin{array}{l}\text { Lokasi toko penyedia gula pasir } \\
\text { mudah dijangkau }\end{array}$ & BPT1.1 & 3,0 & 6,5 & 90,5 \\
\hline & $\begin{array}{l}\text { Supermarket modern menjadi } \\
\text { pilihan konsumen untuk membeli } \\
\text { gula pasir }\end{array}$ & BPT1.2 & 11,5 & 17,0 & 71,5 \\
\hline & $\begin{array}{l}\text { Toko retail / minimarket menjadi } \\
\text { pilihan konsumen untuk membeli } \\
\text { gula pasir }\end{array}$ & BPT1.3 & 8,0 & 19,0 & 73,0 \\
\hline & $\begin{array}{l}\text { Pasar tradisional menjadi pilihan } \\
\text { konsumen untuk membeli gula } \\
\text { pasir }\end{array}$ & BPT1.4 & 10,0 & 31,0 & 59,0 \\
\hline & $\begin{array}{l}\text { Warung dekat rumah menjadi } \\
\text { pilihan konsumen untuk membeli } \\
\text { gula pasir }\end{array}$ & BPT1.5 & 6,5 & 25,5 & 68,0 \\
\hline \multirow[t]{6}{*}{ Promosi } & $\begin{array}{l}\text { Produk gula pasir selalu memberi } \\
\text { diskon }\end{array}$ & BP1.1 & 23,5 & 37,5 & 39,0 \\
\hline & $\begin{array}{l}\text { Produk gula pasir selalu } \\
\text { memberikan promosi berupa } \\
\text { hadiah langsung dari pembelian } \\
\text { gula pasir }\end{array}$ & BP1.2 & 29,5 & 32,5 & 38,0 \\
\hline & $\begin{array}{l}\text { Produk gula pasir merek tertentu } \\
\text { selalu menayangkan iklan tv }\end{array}$ & BP2.1 & 4,5 & 25,0 & 70,5 \\
\hline & $\begin{array}{l}\text { Informasi merek gula pasir yang } \\
\text { saya beli berasal dari media cetak } \\
\text { atay flyer }\end{array}$ & BP2.2 & 28,0 & 35,5 & 36,5 \\
\hline & $\begin{array}{l}\text { Informasi merek gula pasir yang } \\
\text { saya beli berasal dari iklan pop up } \\
\text { di media sosial }\end{array}$ & BP2.3 & 31,5 & 31,5 & 37,0 \\
\hline & $\begin{array}{l}\text { Informasi merek gula pasir yang } \\
\text { saya beli berasal dari iklan pop up } \\
\text { di baliho atau spanduk pinggir } \\
\text { jalan }\end{array}$ & BP2.4 & 37,5 & 32,0 & 30,5 \\
\hline
\end{tabular}


Namun, pada elemen produk hampir seluruh responden memiliki frekuensi relatif yang tinggi karena responden sudah menjawab setuju dan sangat setuju, sehingga hal ini dapat memengaruhi variabel y (perilaku pembelian). Jawaban responden pada kategori netral dianggap sebagai jawaban tidak yakin dan jawaban tersebut dianggap menjadi kategori serupa dengan sangat tidak setuju dan tidak setuju.

Pada elemen bauran pemasaran produk sebagian responden telah setuju bahwa gula pasir harus memiliki kualitas kemasan yang disertai label dan sudah memenuhi standar dan tingkat kekeringan yang baik. Beberapa indikator tersebut telah menunjukkan bahwa konsumen sudah mulai menyadari akan pentingnya pencantuman label pada kemasan dan perlunya penggunaan merek pada produk gula pasir. Berdasarkan hasil wawacara saat pengambilan data, responden yang melakukan pembelian gula pasir selain di pasar tradisional lebih memilih gula pasir bermerek dan gula pasir dengan kemasan yang baik; dengan kelengkapan atribut label. Pada elemen harga, sebagian besar konsumen (77persen) sudah setuju dengan kesesuaian harga yang diberikan oleh produsen gula pasir, jika dilengkapi dengan kemasan dan label sesuai standar. Jawaban responden pada elemen harga sesuai dengan tingkat daya beli konsumen, jika dilihat dari rata-rata pendapatan responden penelitian. Elemen bauran pemasaran tempat dengan persentase tertinggi berada pada indikator lokasi penyedia gula pasir mudah dijangkau oleh konsumen, sehingga hal tersebut dapat menjadi feedback positif terkait distribusi yang sudah baik. Elemen lain dari bauran pemasaran yaitu elemen promosi, pada elemen ini jawaban responden merata, sehingga dapat dilihat bahwa konsumen tidak terlalu merasakan promosi yang telah dilaksanakan produsen.

\section{Perilaku Pembelian Konsumen Gula Pasir}

Perilaku pembelian dibagi menjadi dua tahap, yaitu tahap prapembelian dan tahap pembelian (Sumarwan, 2015). Tahap prapembelian dalam penelitian ini digambarkan melalui atribut apa yang lebih dipentingkan oleh konsumen saat membeli produk gula pasir. Berdasarkan data hasil penelitian (Tabel 3), proporsi terbesar dari atribut yang paling dipentingkan dalam pemilihan produk gula pasir adalah warna $(23,5 \%)$. Atribut warna gula pasir, dilihat oleh konsumen dari plastik kemasan yang transparan sehingga konsumen dapat membandingkan secara langsung warna butiran gula pasir dari berbagai macam merek.
Tabel 3 Perilaku pembelian gula pasir berdasarkan atribut produk yang dipentingkan reponden

\begin{tabular}{lrr}
\hline \multicolumn{1}{c}{ Atribut produk } & Frekuensi & Persentase (\%) \\
\hline Warna & 47 & 23.5 \\
Harga & 41 & 20.5 \\
Brand atau merek & 39 & 19.5 \\
Packaging atau & 38 & 19 \\
kemasan & 35 & 17.5 \\
Label & 200 & 100 \\
\hline Total &
\end{tabular}

Hal ini didukung oleh hasil rilis Standar Nasional Indonesia (SNI), GKP 2 atau gula kristal putih tipe dua dengan warna yang lebih kuning-kecoklatan memiliki rasa lebih manis. Indikator perilaku pembelian produk gula pasir yang digunakan untuk analisis SEM-PLS dalam penelitian ini dilihat dari dua indikator yaitu kesediaan responden untuk membeli produk gula pasir dengan kelengkapan atribut label dan gula pasir bermerek. Responden penelitian cenderung lebih memilih (Tabel 4) produk gula pasir dengan kelengkapan label (78,3\%) dibandingkan dengan gula pasir bermerek $(70,6 \%)$.

Berdasarkan data hasil penelitian pada jenis pertanyaan terbuka, perilaku pembelian konsumen pada produk gula pasir dengan proporsi terbesar merek gula pasir yang dibeli atau dikonsumsi oleh konsumen yaitu adalah gula pasir bermerek. Gula pasir tidak bermerek sering disebut sebagai gula pasir curah yang umumnya dapat dijual di pasar tradisional, toko, ataupun warung sembako. Gula pasir curah merupakan gula pasir yang tidak memiliki label ataupun merek jual sehingga tidak terdapat keterangan lengkap mengenai tanggal kadaluarsa, kode produksi, nama produsen, label BPOM RI, ataupun label Halal MUI.

\section{Hasil Uji Outer Model (Model Pengukuran)}

Uji outer model menggunakan SmartPLS dapat dilihat dari convergent validity, discriminant validity, dan composite reliability.

Tabel 4 Perilaku pembelian konsumen terhadap produk gula pasir

\begin{tabular}{lllllll}
\hline \multirow{2}{*}{ Indikator } & \multirow{2}{*}{ Simbol } & \multicolumn{4}{c}{ Presentase (\%) } \\
\cline { 2 - 6 } & STS & TS & N & S & SS \\
\hline $\begin{array}{l}\text { Perilaku } \\
\text { pembelian gula } \\
\text { dengan label }\end{array}$ & PP1 & 4,8 & 3,4 & 13,5 & 42,8 & 35,5 \\
$\begin{array}{l}\text { Perilaku } \\
\text { pembelian gula } \\
\text { bermerek }\end{array}$ & PP2 & 6,3 & 3,9 & 19,2 & 37,1 & 3,5 \\
\hline
\end{tabular}

Keterangan: STS= sangat tidak setuju; TS= sangat setuju;

$\mathrm{N}=$ netral; $\mathrm{S}=$ setuju; $\mathrm{SS}=$ sangat setuju 


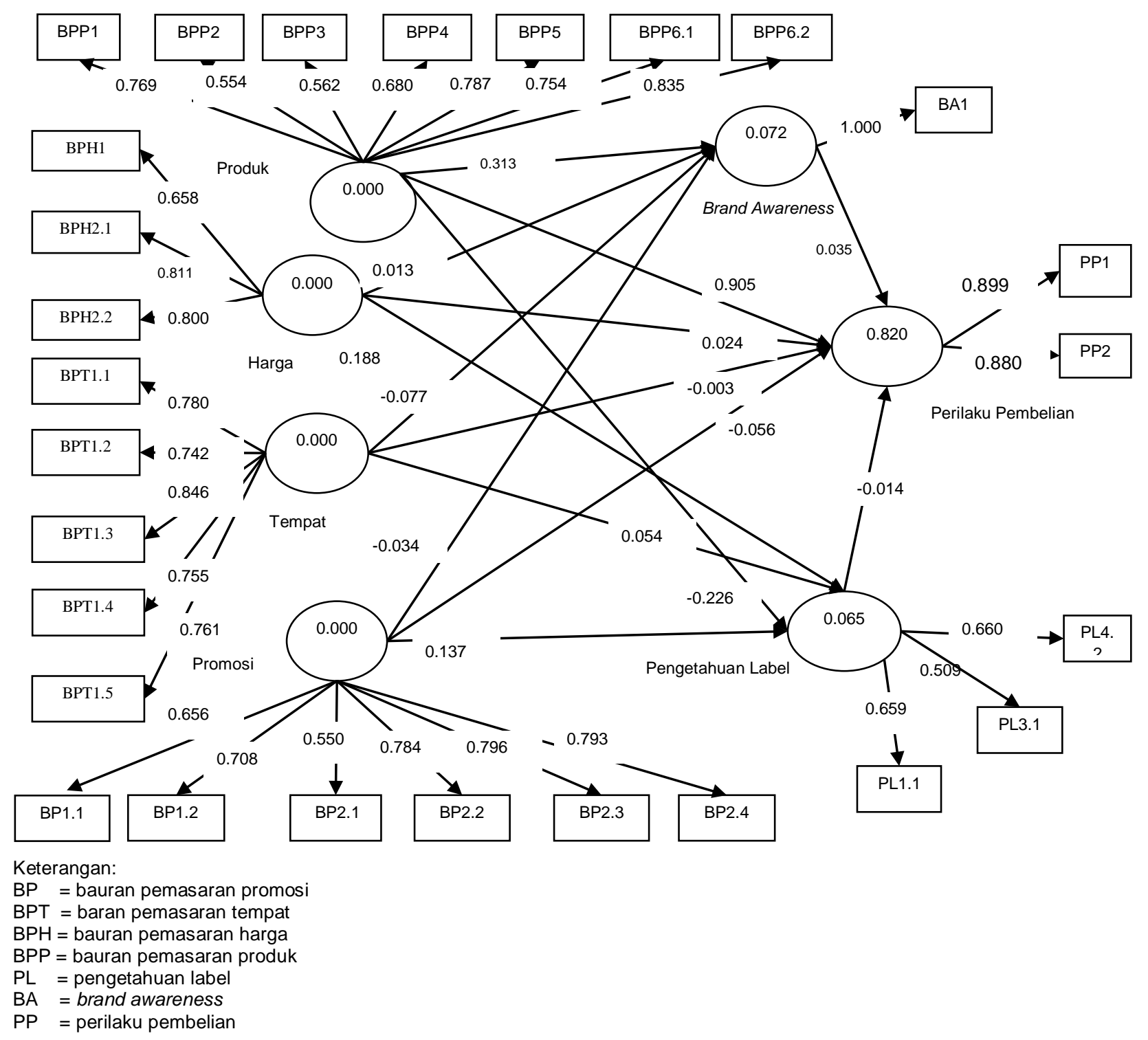

Gambar 2 Model SEM-PLS pengaruh pengetahuan label, brand awareness, dan bauran pemasaran terhadap perilaku pembelian hasil bootstrapping

Validitas construct dilihat dari nilai loading factor untuk tiap indikator construct. Berdasarkan hasil uji dari 34 indikator variabel construct, 27 indikator memiliki nilai loading factor $>0,5$. Sebanyak 7 indikator yang memiliki nilai loading factor $<0,5$ akan dilakukan proses dropping.

Nilai loading factor lebih dari 0,5 membuktikan bahwa indikator tersebut valid sebagai pengukur construct dan telah merefleksikan variabel laten. Discriminant validity yang baik dapat ditunjukkan dari akar kuadrat AVE tiap construct lebih besar dari korelasi antara construct dalam model (Fornell dan Larcker, 1981 dalam Ghozali dan Latan, 2012). Hasil uji yang dilakukan juga menunjukkan nilai AVE masing-masing construct sudah $>0,5$. Selain itu, nilai composite reliability dan Cronbach's alpha sudah diatas 0,6 dan 0,7 sehingga dapat dinyatakan bahwa semua indikator konstruk telah reliabel atau memenuhi syarat pada uji reliabilitas.

\section{Hasil Uji Inner Model (Model Struktural)}

Evaluasi model struktural (inner model) dapat dilihat melalui nilai $R$-squares pada setiap variabel laten endogen sebagai kekuatan prediksi dari model struktural (Ghozali dan Latan, 2012). Model struktural dievaluasi menggunakan koefisien determinan $\left(\mathrm{Uji}^{2}{ }^{2}\right)$ dan koefisien path atau $t$-value (Tabel 5 ). Nilai $\mathrm{R}^{2}$ digunakan untuk mengukur tingkat variasi perubahan variabel independen terhadap variabel dependen. 
Tabel 5 Hasil uji path coefficients

\begin{tabular}{lrrrl}
\hline \multicolumn{1}{c}{ Path } & $\begin{array}{c}\text { Original } \\
\text { sample } \\
(\mathrm{O})\end{array}$ & $\begin{array}{c}\text { Standard } \\
\text { error } \\
(\text { STERR })\end{array}$ & $\begin{array}{c}\text { T-statistics } \\
(|\mathrm{O} / \mathrm{STERR}|)\end{array}$ & Kesimpulan \\
\hline Pegetahuan label $\rightarrow$ perilaku pembelian & $-0,0143$ & 0,0560 & 0,2553 & Tolak hipotesis \\
Brand awareness $\rightarrow$ perilaku pembelian & 0,0351 & 0,0532 & 0,6604 & Tolak hipotesis \\
Bauran pemasaran produk $\rightarrow$ brand awareness & 0,3125 & 0,1085 & 2,8792 & Terima hipotesis \\
Bauran pemasaran harga $\rightarrow$ brand awareness & 0,0127 & 0,1317 & 0,0969 & Tolak hipotesis \\
Bauran pemasaran tempat $\rightarrow$ brand awareness & $-0,0774$ & 0,1455 & 0,5318 & Tolak hipotesis \\
Bauran pemasaran promosi $\rightarrow$ brand awareness & $-0,0335$ & 0,1326 & 0,2531 & Tolak hipotesis \\
Bauran pemasaran produk $\rightarrow$ pengetahuan label & $-0,2258$ & 0,1460 & 1,5464 & Tolak hipotesis \\
Bauran pemasaran harga $\rightarrow$ pengetahuan label & 0,1882 & 0,1995 & 0,9435 & Tolak hipotesis \\
Bauran pemasaran tempat $\rightarrow$ pengetahuan label & 0,0640 & 0,2040 & 0,3137 & Tolak hipotesis \\
Bauran pemasaran promosi $\rightarrow$ pengetahuan label & 0,1371 & 0,1683 & 0,8147 & Tolak hipotesis \\
Bauran pemasaran produk $\rightarrow$ perilaku pembelian & 0,9052 & 0,0533 & 16,9579 & Terima hipotesis \\
Bauran pemasaran harga $\rightarrow$ perilaku pembelian & 0,0237 & 0,0602 & 0,3948 & Tolak hipotesis \\
Bauran pemasaran tempat $\rightarrow$ perilaku pembelian & $-0,0031$ & 0,0621 & 0,0500 & Tolak hipotesis \\
Bauran pemasaran promosi $\rightarrow$ perilaku pembelian & $-0,0560$ & 0,0558 & 1,0035 & Tolak hipotesis \\
\hline
\end{tabular}

Dalam model penelitian ini, terdapat dua variabel laten endogen sehingga nilai $R^{2}$ dari brand awareness, pengetahuan label, dan perilaku pembelian digunakan untuk evaluasi kebaikan model. Berdasarkan hasil uji nilai $R$ squares untuk variabel brand awareness sebesar 0,072. Hal ini menunjukkan bahwa peubah dalam model dapat dijelaskan oleh peubah brand awareness sebesar 7,22 persen; sedangkan sisanya dapat digambarkan oleh faktor-faktor variabel lain yang tidak disertakan pada model.

Untuk nilai $R$-squares 0,819 memiliki arti keragaman variabel perilaku pembelian yang digambarkan oleh brand awareness, pengetahuan label, dan bauran pemasaran sebesar 81,99 persen, sedangkan sisanya dapat dijelaskan oleh variabel lain yang tidak termasuk ke dalam model penelitian ini. Menurut Hair et al. (2011) dalam Fitriyani (2016), nilai $R$-squares $0,75,0,50,0,25$ dan disimpulkan sebagai model yang kuat, moderate, dan lemah. Nilai $R$-squares sebesar 0,064 memiliki arti bahwa pengetahuan label digambarkan oleh bauran pemasaran sekitar 6,4 persen pada Gambar 2.

\section{Pengujian Hipotesis}

Berdasarkan model penelitian ini, tahapan selanjutnya dilakukan pengujian hipotesis melalui uji koefisien jalur (path) pada model persaman struktural. Model struktural merupakan model yang menghubungkan variabel laten eksogenous dengan variabel laten endogenous lainnya. Pengujian hipotesis menggunakan statistik uji $\mathrm{t}$ dengan kriteria pengambilan keputusan sebagai berikut;
Hipotesis diterima jika nilai $\mathrm{t}$ statistik lebih dari 1,96 denga nilai t pada alpha $(0,05)$. Original sample menunjukkan nilai koefisien jalur.

\section{PEMBAHASAN}

Pada pengujian hipotesis 3 sampai hipotesis 6 dalam model penelitian ini, hasil uji pengaruh variabel bauran pemasaran terhadap brand awareness, menunjukkan bahwa hanya elemen produk dari bauran pemasaran yang memiliki pengaruh nyata pada brand awareness. Bauran pemasaran (produk) terbukti dapat meningkatkan brand awareness konsumen karena responden beranggapan bahwa gula pasir harus bermerek dan memiliki kualitas kemasan gula pasir yang sesuai standar, kedua hal tersebut hanya dapat dipenuhi gula pasir bermerek. Hal ini sejalan dengan Dmour, AlZu'bi, dan Kakeesh (2013); Hameed dan Habib (2019); Ozkul dan Tuna (2011); Rahmah, Sumarwan, dan Najib (2018); Sonika (2017); serta Triana (2016) yang menyatakan bahwa terdapat korelasi positif antara elemen produk pada bauran pemasaran dengan brand awareness. Hasil lain juga menunjukkan bahwa ketiga elemen dalam bauran pemasaran seperti harga, tempat, dan promosi tidak memiliki pengaruh pada brand awarenes. Hasil penelitian ini serupa dengan hasil penelitian yang dilakukan Ahmad dan Ahmadvand (2017); Alex (2012); Amiri dan Maoofi (2016); Chattopadhyay, Shivani, dan Krishnan (2010); Conradie, Lombard, dan Klopper (2013); Kurnia dan Widyastuti (2011); Herdana (2015); Hosseini dan Moezzi (2015); serta Nezami (2013). Menurut penelitian Ahmad dan 
Ahmadvand (2017), elemen harga tidak memengaruhi brand awareness karena harga yang ditetapkan tidak berbeda jauh dengan kompetitor. Berdasarkan hasil penelitian ini elemen harga tidak memiliki pengaruh terhadap brand awareness karena harga dari masingmasing produsen gula pasir tidak berbeda jauh sehingga tidak dapat dijadikan pertimbangan konsumen untuk mengingat suatu brand secara spesifik. Elemen tempat tidak memiliki pengaruh signifikan terhadap brand awareness, karena produk gula tersedia dimanapun sehingga tidak memengaruhi tingkat brand awareness konsumen (merek tertentu tidak spesifik dijual di suatu tempat tertentu).

Selain itu, hasil uji juga menunjukkan bahwa tidak ada pengaruh signifikan antara variabel bauran pemasaran terhadap pengetahuan label. Keempat elemen bauran pemasaran; produk, harga, tempat, dan promosi tidak memiliki pengaruh signifikan terhadap pengetahuan label. Hal ini dipicu oleh pengetahuan konsumen terkait label berada pada aspek berbeda dengan indikator-indikator bauran pemasaran yang memiliki empat elemen. Pengetahuan konsumen terkait label merupakan pengetahuan kognitif konsumen yang perlu diketahui sebelum konsumen melakukan keputusan dalam pembelian suatu produk. Hasil penelitian ini sesuai dengan hasil dari penelitian Abril dan Canovas (2016); Aspan, Sipayung, Muharrami, dan Ritonga (2017); serta Novrianto, Restuhadi, dan Eliza (2015). Penelitian Novrianto et al. (2015) menyebutkan bahwa bauran pemasaran tidak memiliki pengaruh terhadap pengetahuan label karena atribut pada label tidak terlalu dipentingkan sebagai pertimbangan konsumen untuk melakukan keputusan pembelian. Hasil penelitian ini juga menunjukkan bahwa tidak terdapat peningkatan signifikan dalam hasil penjualan sebelum dan sesudah pemberian label pada kemasan.

Selanjutnya, hasil analisis menunjukkan bahwa bauran pemasaran produk secara langsung berpengaruh nyata terhadap perilaku pembelian konsumen. Hasil penelitian ini didukung oleh penelitian Ahmad dan Sulehri (2018); Beyene (2018); Dowdy (1995); Katana (2014); Rahman, Alamzab, dan Ayaz (2018); Shaik dan Venkataiah (2013); Shakir, Shakir, dan Zaman (2012); Sisodiya (2018); Wongleedee (2015). Menurut penelitian yang dilakukan Katana (2014); Rahman et al. (2018); serta Shakir et al. (2012) produk memiliki pengaruh paling besar terhadap perilaku pembelian dengan atribut produk seperti kualitas, kemasan, dan nama merek (brand). Pada hasil uji hipotesis 8 hingga 10, elemen bauran pemasaran lainnya tidak memiliki pengaruh pada perilaku pembelian. Hal ini sejalan dengan penelitian Payson dan Karunanithy (2016); Sethi dan Sharma R (2016); Sharma, Nasreen, dan Mishra (2017); Siringoringo (2004); dan Tekletsion (2019). Ketiga elemen bauran pemasaran lainnya, selain produk tidak memiliki pengaruh terhadap perilaku pembelian. Hasil juga menunjukkan bahwa harga merupakan atribut yang berada pada urutan kedua setelah warna (elemen produk) sehingga dapat disimpulkan bahwa konsumen tidak mempertimbangkan elemen lain seperti harga, promosi, dan tempat dalam melakukan perilaku pembelian gula pasir. Responden penelitian lebih mementingkan atribut warna dibandingkan dengan atribut lain seperti label, merek, kemasan, dan harga untuk melakukan pembelian gula pasir. Atribut warna termasuk dalam indikator dalam bauran pemasaran produk yang memiliki pengaruh terhadap perilaku pembelian. Pada elemen tempat tidak terdapat pengaruh signifikan terhadap perilaku pembelian karena pada penelitian ini lingkup konsumsi hanya terbatas untuk konsumsi pribadi dan rumah tangga, sehingga tempat membeli gula pasir tidak terlalu berpengaruh jika mempertimbangkan biaya distribusi dan kemudahan mendapatkan gula pasir tersebut (tersedia dimanapun).

Hasil uji juga menunjukkan bahwa brand awareness tidak memiliki pengaruh signifikan terhadap perilaku pembelian. Hal ini sejalan dengan penelitian Chuchu dan Ndlela (2016); Jamali dan Khan (2018); Suroyo (2012); dan Yar (2015). Pada penelitian ini tingkat brand awareness konsumen terhadap hampir seluruh merek gula pasir yang beredar di pasaran masih pada tahap brand recognition, sehingga tidak berpengaruh terhadap perilaku pembelian. Faktor lain yang menyebabkan brand awareness tidak memiliki pengaruh terhadap perilaku pembelian karena gula pasir merupakan produk komoditas sehingga konsumen tidak terlalu mempertimbangkan brand.

Hasil uji pengaruh pengetahuan label pada kemasan gula ditemukan tidak memengaruhi perilaku pembelian. Pengetahuan label adalah pengetahuan subjektif konsumen terhadap berbagai informasi yang diperoleh melalui pengalaman atau lingkungan konsumen, sedangkan perilaku pembelian dilakukan konsumen setelah melakukan keputusan. Pengetahuan konsumen menjadi salah satu aspek pertimbangan sebelum konsumen 
memutuskan membeli suatu produk. Namun berdasarkan hasil penelitian ini, pengetahuan konsumen berada pada urutan bawah sehingga tidak terlalu dipentingkan konsumen. Pengetahuan konsumen terkait label tidak diimplementasikan pada perilaku pembelian. Hal ini disebabkan oleh tingkat pengetahuan konsumen terkait label yang termasuk dalam kategori rendah. Hal ini sejalan dengan penelitian sebelumnya yang telah dilakukan oleh Baka et al. (2016); Giyatno dan Sumarsono (2012); Mazhar, Daud, Bhutto, dan Mubin (2015); Saputri dan Saraswati (2017); Stanley (2007); dan Taufique, Vocino, dan Polonsky (2016) yang menyebutkan bahwa tidak terdapat pengaruh pengetahuan konsumen terkait informasi pada kemasan produk (simbol-simbol, pernyataan, dan istilah pada label produk) terhadap perilaku pembelian konsumen. Konsumen perlu diberi edukasi untuk lebih cermat dalam menentukan pembelian suatu produk, sehingga dapat menjadi konsumen cerdas.

\section{SIMPULAN DAN SARAN}

Pada penelitian ini, lebih dari sebagian responden memiliki tingkat pengetahuan label terkategori rendah. Hasil penelitian menunjukkan bahwa sebanyak 8 dari 10 responden memilih elemen produk sebagai elemen yang paling dipentingkan konsumen, dibandingkan dengan elemen lain seperti harga, promosi, atau tempat. Hasil uji pengaruh menunjukkan bahwa elemen produk bauran pemasaran berpengaruh terhadap brand awareness dan elemen produk bauran pemasaran juga berpengaruh terhadap perilaku pembelian. Brand awareness dan pengetahuan label tidak berpengaruh terhadap perilaku pembelian konsumen gula pasir. Bauran pemasaran elemen harga, tempat, dan promosi tidak berpengaruh terhadap pengetahuan label, brand awareness, dan perilaku pembelian. Temuan ini menegaskan bahwa perilaku pembelian konsumen gula pasir tidak dipengaruhi pengetahuan konsumen terkait label, namun beberapa atribut lainnya dari produk seperti warna butiran gula pasir, harga, dan merek.

Saran yang diberikan dalam penelitian ini yaitu untuk meningkatkan kesadaran konsumen terkait pentingnya pengetahuan label, agar konsumen lebih cermat dalam memilih produkproduk sesuai SNI. Selain itu, penelitian ini masih menemukan konsumen dengan pengetahuan yang rendah, sehingga konsumen tidak keberatan jika harus membeli dan mengonsumsi gula pasir curah dengan kemasan seadanya, tanpa merek, dan tanpa label. Hal ini mengindikasikan perlunya pemberian edukasi tentang cara memilih produk dengan lebih cermat. Penelitian selanjutnya untuk melihat perilaku konsumsi produk kebutuhan dasar selain gula pasir perlu dilakukan dengan cakupan contoh yang lebih luas.

\section{DAFTAR PUSTAKA}

[BKPN] Badan Perlindungan Konsumen Nasional. (2007). Hasil kajian badan perlindungan konsumen nasional di bidang pangan terkait perlindungan konsumen. Jakarta, ID: Departemen Perdagangan Republik Indonesia.

[BPOM] Badan Pengawas Obat dan Makanan. (2016). Peraturan Kepala Badan Pengawas Obat dan Makanan Republik Indonesia Nomor 13 Tahun 2016 tentang Pengawasan Klaim pada Label dan Iklan Pangan Olahan Pasal 1 poin 14 poin 16. Retrieved from https://standarpangan.pom.go.id/dokumen/ peraturan/2016/PerKa_BPOM_No_13_Ta hun_2016_tentang_Klaim_pada_Labè-_da n_lklan_Pangan_Olahan.pdf

[BPS] Badan Pusat Statistik. (2017). Rata-Rata Konsumsi Per Kapita Seminggu Beberapa Macam Bahan Makanan Penting 20072018. Retrieved from https://www.bps.go.id/statictable/2014/09/0 8/950/rata-rata-konsumsi-per-kapitaseminggu-beberapa-macam-bahanmakanan-penting-2007-2018.html

[Permen] Peraturan Menteri. (2015). Peraturan Menteri Perdagangan Republik Indonesia Nomor: 73/M-DAG/PER/9/2015 Tentang Kewajiban Pencantuman Label dalam Bahasa Indonesia Pada Barang. Pasal 2. Retrieved from http://jdih.kemendag.go.id/backendx/image /old/2015/09/28/kewajiban-pencantumanlabel-dalam-bahasa-indonesia-padabarang-id-1444046296.pdf

Abril, C., \& Canovas, B. (2016). Marketing mix effects on private labels brand equity. European Journal of Management and Business Economics, 25(3), 168-175. doi:doi.org/10.1016/j.redeen.2016.09.003.

Ahmad, M., \& Sulehri, N. (2018). Retail marketing mix and trust in store to purchase behavior with the mediation of purchase intention: A study of retail industry in Pakistan. Journal Asia Proceedings of Social Sciences, 2(3), 96100. 
Ahmad, S., \& Ahmadvand, F. (2017). The explanation of model consumer responses to brand equity based on marketing mix effort, corporate image, and brand equity relation (Case study: Butane industrial company). International Journal of Applied Business and Economic Research, 15(23), 627-630.

Alex, N. (2012). An enquiry into selected marketing mix elements and their impact on brand equity. The IUP Journal of Brand Management, 9(2), 29-43.

Amiri, S., \& Maoofi, F. (2016). The relationship between brand awareness, market outcome, brand equity, and marketing mix. International Journal Markets and Business Systems, 2(1), 72-83. doi:doi.org/10.1504/IJMABS.2016.078108.

Anggraini, V., Prasmatiwi, F., \& Santoso, H. (2013). Tingkat kepuasan dan loyalitas konsumen gulaku di kota Bandar Lampung. Jurnal IImu Agribisnis (JIIA), 1(2), 151-154.

Aspan, H., Sipayung, I., Muharrami, A., \& Ritonga, H. (2017). The effect of halal label, halal awareness, product price, and brand image to the purchasing decision on cosmetic products (Case study on consumers of Sari Ayu Martha Tilaar in Binjai City). International Journal of Global Sustainability, 1(1), 57-65. doi:doi.org/ 10.5296/ijgs.v1i1.12017

Baka, W. K., Rianse, U., Sidu, D., Widayati, W., Cahyono, E., Abdullah, W. G., Rianse, I. S., La Zulfikar, Z., La Abdi, A., \& Baka, L.R. (2016). Customer behaviour model of brown sugar commodity. Int. J. Business Innovation and Research, 11(3), 444-460.

Beyene, T. (2018). The impact of marketing mix elements on the consumer buying behaviour, in the case of retail supermarkets in Addis Ababa (Theses). Addis Ababa, ET: ST. Mary's University

Chattopadhyay, T., Shivani, S., \& Krishnan, M. (2010). Marketing mix elements influencing brand equity and brand choice. Vikalpa: The Journal for Decision Makers, 35(3), 67-81. doi:doi.org/10.1177/ 0256090920100305

Chuchu, T., \& Ndlela, T. (2016). Celebrity endorsement advertising: Brand awareness, brand recall, brand loyalty as antecedence of south african young customers purchase behaviour. Journal of Economics and Behavioral Studies, 8(2), 79-90. doi:10.22610/jebs.v8i2.1256.g1230.
Conradie, E., Lombard M., \& Klopper H, B. (2013). The influence of eleven ps: An internal marketing and brand awareness perspective in a service environment. Journal Southern African Business Review, 18(1), 100-118. doi:10.25159/1998-8125/5647.

Dmour, H., Al-Zu'bi, Z., \& Kakeesh. (2013). The effect of services marketing mix elements on customer-based brand equity: An empirical study on mobile telecom service recipients in Jordan. International Journal of Business and Management, 8(11), 1324. doi:10.5539/ijbm.v8n11p13

Fitriyani, D. (2016). Analisis perilaku pembelian oral nutritional supplements (ONS) untuk anak-anak (Thesis). Bogor, ID: Institut Pertanian Bogor.

Ghozali, I., \& Latan, H. (2012). Partial least square: Konsep, teknik dan aplikasi smart PLS 2.0 M3. Semarang, ID: Badan Penerbit Universitas Diponegoro.

Giyatno, Y., \& Sumarsono. (2012). Analisis sikap dan pengetahuan konsumen terhadap ecolabelling serta pengaruhnya pada keputusan pembelian produk ramah lingkungan. Performance, 15(1), 70-85.

Goodson, M. (2013). The impact of labeling: Organic sales and recommendations for gaining consumer trust (Dissertation). Minneapolis, US: Capella University

Hameed, S., \& Habib, H. (2019). The impact of marketing on brand equity. Journal of Marketing and Logistics, 2(1), 43-55.

Herdana, A. (2015). Analisis pengaruh kesadaran merek pada produk asuransi jiwa Prudential Life Assurance: Studi pada pru passion agency Jakarta). Jurnal Riset Bisnis dan Manajemen, 3(1), 1-18.

Hosseini, M., \& Moezzi, H. (2015). Exploring impact of marketing mix on brand equity in insurance industry case study: Asia insurance firm Iran. Journal of Asian Scientific Research, 5(1), 38-45.

Jamali, M., \& Khan, R. (2018). The impact of consumer interaction on social media on brand awareness and purchase intention case study of Samsung. Journal of Marketing and Logistics, 1(2), 114-129.

Katana, M. (2014). The influence of marketing mix variables on consumer buying behavior of insecticides treated bed nets in Nairobi Country (Thesis). Nairobi, KE: University of Nairobi 
Kotler, P., \& Keller, L. (2017). Manajemen pemasaran (Edisi ke-13 Jilid 1). Jakarta, ID: Erlangga.

Kurnia, W., \& Widyastuti. (2011). Pengaruh kesadaran merek, kesan kualitas, dan asosiasi merek terhadap keyakinan pelanggan dalam membeli pasta gigi merek Pepsodent (studi Desa Sumberagung Bojonegoro). Jurnal Bisnis dan Manajemen, 3(2).

Mazhar, M., Daud, S., Bhutto, S., \& Mubin, M. (2015). Impact of product packaging on consumer buying behavior: Evidence from Karachi. Journal of Marketing and Consumer Research, 16, 35-42.

Muslim, E., \& Indriani, D. (2014). Analisis pengaruh eco-label terhadap kesadaran konsumen untuk membeli green product. Jurnal Manajemen Teknologi, 13(1), 66-76.

Nezami, P. (2013). The reviewing the impact of marketing mix on brand equity (case study: ETKA Stores). Journal of Novel Applied Sciences, 2(10), 517-521.

Novrianto, Restuhadi, F., \& Eliza. (2015). Evaluasi konsumen terhadap atribut produk bauran pemasaran jamur tiram pusat budidaya jamur Riau (Pusdamuri). Jurnal Online Mahasiswa (JOM FAPERTA), 2(1), 1-11.

Ozkul, E., \& Tuna, P. (2013). The relationship between the brand equity and the marketing mix elements that affects the consumer's buying behaviors: A research in 5 star hotels in Istanbul. Journal of Global Strategic Management, 9(2), 263285.

Payson, S., \& Karunanithy, M. (2016). Impact of marketing mix on buying behaviour (a case study of motorbike buyers in Jaffna District). EPRA International Journal of Economic and Business Review, 4(1), 132-127.

Pupuani, N., \& Sulistyawati, E. (2013). Pengaruh bauran pemasaran terhadap kepuasan konsumen dan perilaku pembelian ulang: Studi kasus pada produk pasta gigi merek pepsodent di Kota Denpasar. E-Jurnal Manajemen, 2(6), 683699.

Putri, M., Darus, H. M., \& Ayu, S. (2012). Analisis faktor yang memengaruhi konsumsi gula pasir curah dan proses keputusan pembelian konsumen gula pasir curah di Kota Medan: Studi kasus di pasar tradisional di Kecamatan Medan Kota,
Kota Medan. Journal on Social Economic of Agriculture and Agribusiness, 3(3), 1-11.

Rahmah, K., Sumarwan, U., \& Najib, M. (2018). The effect of brand equity, marketing mix, and lifestyle toward purchase decision at coffee shop in Bogor. Journal of Consumer Sciences, 3(2), 1-15.

Rahman, M., Alamzab., \& Ayaz, M. (2018). The impact of marketing mix on customer buying behavior: A case study of footwear industry. NUML International Journal of Business \& Management, 13(1), 1-7.

Rasyid M. (2016). Analisis gaya hidup, inovasi produk, dan bauran pemasaran terhadap keputusan pembelian produk hen's instant omelette: Studi kasus pada PT. Eco Nature Multiindo. (Thesis). Bogor, ID: Institut Pertanian Bogor.

Saputri, M., E., Saraswati, T., G. (2017). Indonesia consumer's purchase decisions and private label brands: Study of superindo retailer. Proceeding Book of The 3rd International Conference on Science, Technology, and Humanity, 177-183.

Sethi, V., \& Sharma, R. (2016). Determinants of purchase behaviour towards green FMCG products. Journal of Global Information and Business Strategy (J-GIBS), 8(1), 814.

Setiawati, M., \& Lumbantobing, R. (2017). Pengaruh promosi dan kemasan terhadap keputusan pembelian produk chitato yang dimediasi oleh brand awareness. Jurnal Manajemen Bisnis, 12(1), 75-86.

Shaik, S., \& Venkataiah, S. H. (2013). Changing role of green marketing mix in consumer buying behaviour - an empirical investigation. Asia Pacific Journal of Marketing \& Management Review, 2(11), 132-138.

Shakir, H., Shakir, M., \& Zaman, K. (2012). The impact of effective marketing strategy on buying behavior of the international consumer. Academia Arena, 4(12), 11-17. doi:10.7537/j.issn.1553-992X

Sharma, Y., Nasreen, R., \& Mishra, V. (2017). Impact of consumer-centric marketing-mix on purchase behavior of non-core food items: An empirical study of urban subsistence marketplace. Asian Journal of Managerial Science (AJMS), 6(2), 28-39. doi:10.35629

Sisodiya, P. (2018). The impact of marketing mix model/elements on consumer buying behaviour: A study of FMCG products in 
Jaipur City. International Journal of Technical Research \& Science, 3(1), 2931. doi:10.30780/IJTRS.V3.11.2018.016

Sonika. (2017). Effect of marketing mix elements on brand awareness of consumer durables (Thesis). Patiala, IN: Thapar University

Sumarwan, U. (2015). Perilaku konsumen: Teori dan penerapannya dalam pemasaran. Bogor, ID: Penerbit Ghalia Indonesia.

Sunaryo, \& Sudiro, A. (2018). The impact of brand awareness on purchase decision: Mediating effect halal logo and religious beliefs on halal food in Malang Indonesia. Australian Academy of Business Leadership, 4(1), 28-35.

Suroyo, M. (2012). Analisis faktor pengaruh kelompok acuan terhadap brand awareness dan perannya dalam pemilihan merek susu formula bayi (Thesis). Bogor, ID: Institut Pertanian Bogor
Taufique, K. M. R., Vocino, A., \& Polonsky, M. J. (2016). The influence of eco-label knowledge and trust on pro-environmental consumer behaviour in an emerging market. Journal of Strategic Marketing, 25(7), 511-529.

Tekletsion, A. (2019). The effect of marketing mix on consumer buying behavior of small and medium enterprises (SMEs) in Addis Ababa: The case of lideta, Kolfe-Keraniyo and Arada Sub Cities (Thesis). Addis Abeba, ET: Addis Abeba University

Triana, S. (2016). The effect of marketing mix toward brand awareness of pantene shampoo: A study case of pantene shampoo at carefour hypermarket Kota Kasablanka (Thesis). Jakarta, ID: President University

Wongleedee, K. (2015). Marketing mix and purchasing behavior for community products at traditional markets. Procedia: Social and Behavioral Sciences, 197, 2080-2085. doi:10.1016/j.sbspro. 2015.07.323. 